\title{
GLOBAL MEDIA INDUSTRY IN POSTMODERNISM: DOMINATION OF BROADCASTING AND THE TRADITION OF PUBLISHING
}

The aim of this paper is to point out the changes brought by the postmodernism in the global media industry. Modernism was crated simultaneously with the development of the publishing and it lasted several hundred years. Postmodernism was formed in the womb of broadcasting and in just a few years it took over the global market which has been under the control of the publishing houses for several hundred years. The two economic crises at the beginning of the $21^{\text {st }}$ century marked the entry of the global media industry into the mature phase. By entering the mature phase, the media markets of the most economically developed countries had stabilized. Revenues were no longer recording high growth rates and some countries have started to record a negative growth rates in the past five years. In the global market, several global vertically integrated corporations positioned themselves by employing the takeover strategies, which pushed out the smaller competitors from the market.

The period of maturity had revealed the specifics of the media industry and the need for interdisciplinary scientific approach. Analyzing the development of certain categories of the medial industry in different geographic areas it is clear that threw are significant differences in the degree of their development. This was influenced by various factors of which the most important ones are recognized in the historical development and the cultural diversities of the certain geographical areas. Economies, as a scientific discipline, gave its significant contribution to the study of the media industry relatively late, at the end of the twentieth century and become an equal partner to other sciences that were already represented in the analyses. The media industry, as a typical representative of postmodernism, requires a holistic approach in order to find answers to the asked questions.

Key words: broadcasting, management, media industry, postmodernism, publishing

Joško Lozić, MSc, Department of Professional Studies, University of Split, Zagreb, Croatia, e-mail: josko.lozic@gmail.com

* Anta Rončević, PhD, University North, Varaždin, Croatia, e-mail: ante.roncevic@gmail.com Marin Milković, PhD, University North, Varaždin, Croatia, e-mail: rektor@unin.hr 


\section{Introduction}

In 1450, when Guttenberg printed the first song on the table with movable type, the publishing history had begun. The printing press was born, and the social processes were set out in a new direction. Later on the scholars of different disciplines would deal with this event and among them would be those who marked the middle the middle of the fifteenth century as the beginning of modernism. The possibility of printing books and dissemination of knowledge marked the beginning of the end for scholasticism. As the aphorist Georg Fridrich Lichtenberg later wrote: More than gold, lead has changed the world. And more than lead in musket, the lead in the printer's type case ${ }^{1}$. The development path for the Enlightenment had been opened and the knowledge and insights on reason and experience would take primacy to this day.

The journey from the invention of the printing press until the development of the media was not strewn with roses. It took more than 250 years until the first newspaper were printed the ones that we could identify with contemporary understanding of the newspaper as a medium. The development was slow due to various factors and apart from the factors related to the development of the printing technology, the environmental factors also had a large impact. The printing of books was limited because of underdevelopment education structure and insufficient number of literate people who would become the consumers of the publishing product. In 1947, Theodor Adorno and Max Horkheimer published the Dialectic of Enlightenment, where they had provides an overview of the development of the capitalist society from the Enlightenment to the modern capitalism. In the second sentence of the book, they dad already referred to the Enlightenment: The fully Enlightenment earth radiates disaster triumphant ${ }^{2}$.

Between 1775 and 1848 a new technical, economic, social and political system was established the first liberal and industrial capitalism. The system factory production was developed early in the Manchester dominated England, especially in the textile industry. In the 1850, the factory system model, although it had not become ubiquitous in West Europe, still became the "production paradigm": In that way, primarily industrialist and then a much wider social circles considered normal or modern production, i.e. social organization ${ }^{3}$. Modernism made its way into everyday life through the dissemination of contemporary art, the products of the consumer society, new technologies and new forms of transport and communications. The rate at which the modernism crated new and colonized

Kunczik, M. (2014): “Masovni mediji i njihov utjecaj na društvo”, ed. Malović, S., Masovno komuniciranje, Zagreb, Golden marketing - Tehnička knjiga.

2 Kunzmann, P., Burkard, F. P., Wiedmann, F. (2001): Atlas filozofije, Zagreb, Golden Marketing.

3 Vercellone, C., ed. (2007): Kognitivni kapitalizam, Zagreb, Politička kultura nakladnoistraživački zavod. 
world can be subsumed under the concept of modernization - a term denoting processes of individualization, secularization, industrialization, bureaucratization and rationalization, which have constituted the modern world ${ }^{4}$.

The beginning of the twentieth century would be marked by structural theories, migration of the capital to the new world and previously unheard of development of the capitalist mode of production. All that would result in urbanization and migration of the free labor force to the cities. A critical mass was created which would give a new wing in the sails of journalism and publishing. Already in the first quarter of the twentieth century, technological advances were going to lead to the invention of radio and soon after that to the first forms of television. The contours of contemporary media industry would be created even before the mid-twentieth century.

\section{Divergence and the development of the media industry}

The media industry was built on the foundations of publishing as a representative example of an industry which characterized the modernism. The twentieth century, the spread of capitalism, the development of innovations and the growth of productivity created conditions for the divergence of different forms of the organized production. The divergence within the media industry was reflected in the form of differences in the development of journalism as the old sector of the industry, and electronic media, radio and television as the new sectors of the industry. Divergence had existed for a long time even between radio and television, because it took time for the television to accomplish sufficient revenues, which allowed an independent development. Separation of television from the radio, based on sufficient income, could be identified as the beginning of the end of the publishing reign. Broadcasting had unstoppably moved toward taking over the domination of the media industry.

Two fundamental factors were favorable for the development of broadcasting. First, the twentieth century, especially the period after the World War II brought, by then, an unprecedented development of science as well as the related discoveries. The growth of economy, based on the investments in the development and improvements, enabled the technological development that marked the twentieth century. The television and the media industry as a whole developed on this track. And second, the period after the World War II is known as the age of Keynesianism and the welfare state. The accomplishments of the welfare state use broadcasting for their development.

Best, S. and Kellner, D. (1991): Postmodern Theory - Critical Interrogations, New York, The Guilford Press.

Vol. 12, No 3, 2015: 197-214 
Table 1: The growth of production per capita since the industrial revolution

\begin{tabular}{|c|c|c|c|c|c|}
\hline $\begin{array}{c}\text { The average annual } \\
\text { growth }\end{array}$ & $\begin{array}{c}\text { World production } \\
\text { per capita }\end{array}$ & $\begin{array}{c}\text { Europe } \\
(\%)\end{array}$ & $\begin{array}{c}\text { America } \\
(\%)\end{array}$ & $\begin{array}{c}\text { Africa } \\
(\%)\end{array}$ & $\begin{array}{c}\text { Asia } \\
(\%)\end{array}$ \\
\hline $1700-2012$ & 0.8 & 1.0 & 1.1 & 0.5 & 0.7 \\
\hline Of which: & 0.1 & 0.1 & 0.4 & 0.0 & 0.0 \\
\hline $1700-1820$ & 0.9 & 1.0 & 1.5 & 0.4 & 0.2 \\
\hline $1820-1913$ & 1.6 & 1.9 & 1.5 & 1.1 & 2.0 \\
\hline $1913-1950$ & 0.9 & 0.9 & 1.4 & 0.9 & 0.2 \\
\hline $1950-1970$ & 2.8 & 3.8 & 1.9 & 2.1 & 3.5 \\
\hline $1970-1990$ & 1.3 & 1.9 & 1.6 & 0.3 & 2.1 \\
\hline $1990-2012$ & 2.1 & 1.9 & 1.5 & 1.4 & 3.8 \\
\hline $1950-1980$ & $\mathbf{2 . 5}$ & $\mathbf{3 . 4}$ & $\mathbf{2 . 0}$ & $\mathbf{1 . 8}$ & $\mathbf{3 . 2}$ \\
\hline $1980-2012$ & $\mathbf{1 . 7}$ & $\mathbf{1 . 8}$ & $\mathbf{1 . 3}$ & $\mathbf{0 . 8}$ & $\mathbf{3 . 1}$ \\
\hline
\end{tabular}

Source: Piketty, T. (2014): Kapital u 21. stoljeću, Profil knjiga, Profil International, Zagreb

Average growth of production, in the period after the World War II until the beginning of the seventies and the oil crisis, were high and stabile. In Europe, the average was 3,8 \% and in America 1.9\%. After the increase in oil prices, but also the slowdown of the accelerated reconstruction of war-torn Europe, the growth rates slowed to an average of 1,9\% in Europe and 1.6\% in America. Such log and steady growth enabled the development of the infrastructure of broadcasting.

\section{Convergence and the development of multimedia corporations}

The period of the eighties of the twentieth century was marked by a sudden fall in the average production per capita, but that primary related to Europe and Asia, where they had exhausted the excising growth models. In the United States, that trend was not felt because the growth rates were relatively uniform and stable. The period from the Word War II until the mid-seventies in Europe was often called glorious thirty, and in some countries, especially in France, they are looked upon with nostalgia even today. Upon completion of the cycle of renewal and development of the industry in Europe, the production growth rates had equalized with rates in the USA, and in technological development, Europe was at the top of the world along the USA.

The growth rates of counties that had lost World War II, primarily Germany and Japan, reached the growth rates of the Anglo-Saxon countries, the United States and Great Britain. Such development of the situation led to a review of the policy of the welfare state. National markets of the United States and Great Britain were flooded with domestic products and conservative political movements 
which came into power in the Anglo-Saxon countries, reversed the achievements of Keynesianism and opened the way for new liberalism. State interventionism had pulled back again, under the surge of original capitalism with its roots in the $19^{\text {th }}$ century.

The liberalization movement, that began around 1980, or indeed nationalization, which had started in 1945, do not deserve such excessive celebration nor excessive attacks. France, Germany and Japan would have probably made up for the delay of growth after the collapse in $1914-1945$, no matter what policy they were following. In can only be said that the state intervention was not harmful for them ${ }^{5}$. Liberalism is based on the principle of individual freedom and democracy, which results in decentralization and the turning of the levers of authority towards individuals. In modernism, the strengthening of individualism causes the disappearance of feudalism ${ }^{6}$. The political foundations of liberalism are being expressed in the fundamental concepts of modern democracy, such as the theory of contract and popular sovereignty, power-sharing, system of rights and freedoms of man and citizen, the rule of law, parliamentary democracy, equality, justice, legality and legitimacy. The economic fundamentals of liberalism are private property, free competition, market economy, the principle of laissez-faire, or the spontaneity of the market?

With the abolition of state intervention and the introduction of liberal social and economic doctrines the foundations of development of global corporations were being created. The development stage had started, which was described by Marx as imperialist capitalism and which is based on the foundations of the rule of capitalist corporations. According to Marx's understanding of the historical development of the capitalism, we could draw conclusion that the period after the eighties had followed third phase of Marx's teaching. After the concentration and accumulation, comes the pauperization. The fourth and last stage is the crisis, which we would experience in the $21^{\text {st }}$ century after the deflation of the financial bubbles. Marx was the original Hegelian, and Hegel himself was a supporter of the strong state and thought that the state should limit individualistic and egoistic aspirations of individuals everywhere where it comes to ethical ideal. However, later on even Hegel had softened that attitude and according to Lunacek ${ }^{8}$ Hegel softened the thesis on the superiority of the state against individuals, with a famous saying that the world history is nothing other than the progress of the consciousness of freedom.

Piketty, T. (2014): Kapital u 21. stoljeću, Profil knjiga, Profil International, Zagreb.

6 Hicks, R.C.S. (2004): Expaining Postmodernism - Scepticism and Socialism from Rousseau to Foucault, Wisconsin, Scholargy Publishing, Tempe, Arizona and New Berlin/Milwaukee. Milardović, A. (1996): Uvod u politologiju, Pan - liber, Osijek.

8 Lunaček, V. (2004): Povijest ekonomskih doktrina, Dom i svijet, Ekonomski fakultet, Zagreb.

Vol. 12, No 3, 2015: 197-214 
Abandonment of the state interventionism and liberalization of the market in the early eighties would ring the death bells for modernism. Globalization appeared like the tide. Corporations were merging together and were spreading on regional and then to the global market. In developed countries the age had come which would be later recognized as a post-industrial society, with all the features that it brings. Conditions had been created for the development of multimedia corporations. In only about the years, the American multimedia corporations were going to control the global media market. Digitalization would enable the final seal for the domination of multi media corporation. Media content was going to be distributed via different platforms and the ease of its distribution and use would be the leverage for the economies of scales of global cross media corporations.

\section{Postmodernism and the society of spectacle}

Postmodernism brought the total predominance of broadcasting over publishing. Or at least in those market segments which would grow along with the broadcasting or in those parts of the world which would accept broadcasting and the media spectacle as part of the social processes that became part of the cultural identity. Post-industrial society, which was developing of the basis of the development of postmodernism, ease going to be marked by two factors. The first is reflected through the blurring of borders between the environmental of the organizations and the organizations themselves, that some authors called the blurred boundaries, and the second one, post-industrial society would bring the supremacy to the economy of knowledge, which was based on human resources and mobility of human resources without a solid domicile residence.

In a very short period of time, we had become witnesses to the growth and consolidation of the large transnational conglomerates and media infrastructures, in almost every corner of the world. With the persistent pressure from media organizations and financial markets, the waves of innovations were caused, which radically changed the manufacture, distribution, consumption an use of the media products. The generations born after the eighties grew up with global multimedia organizations. Publishing had marked the modernism. Broadcasting, digitalization, Internet and vertically integrate cross media corporations would mark the postmodernism.

Modernism built capitalism of solid boundaries of organizations. The publishing and newspaper industry were created and with the development of modern methods of production, solid foundations for the development of science and innovation were set. Science and innovation would be the ones that led to the complete change of direction in the media industry, thought what Schumpeter

Editorial Collective (2014): "Welcome to Media Industries", Media Industries Journal 1, 1-4. 
had called creative destruction. Electronic market would prevail over other types of market. Postmodernism was going to be blur the boundaries of organization of the modern corporations, including the multimedia. As Grant ${ }^{10}$ cold it breaking down corporate boundaries. The dominant media products of modernism were in the physical form and were intended for the distribution via the classic distribution channels.

The adoption of digital technology enabled content to be shared among many different platforms. Media companies now distribute content to multiple platforms and devices ${ }^{11}$. Across the media, many firms have responded to digital convergence by adopting a multi-platform strategy in relation both to productive and to exploitation of their content assets ${ }^{12}$. The convergence was taking place in three main areas: content (media) computer platforms (information technology) and communications (telecom and broadband operators). A subset of industry - level convergence is corporate convergence - whereby companies from one sector acquire or ally with other firms, or start new ones, in another of the converging industries ${ }^{13}$.

Media products of postmodernism are the combination of physical products and services. They are indented for use on a variety of platforms. The value of the products is not reduced regardless of the number of consumers that use the product and the time of consumption usually does not depended upon the environmental factors. They are available almost everywhere and at any time. Products of the media industry are also the products of the culture, but at the same time they are the merchandise which is being exchanged on the market.

However, this kind of development had also its negative consequences. Discussion were led at various levels about the question of endangering the culture of origin of certain parts of the world, as well as about the subject of how globalization and media industry were affecting the products of culture and everything related to culture identity. Marx, who was quoted by the postmodernist, represented the position that the value of a commodity is determined by how useful a thing is. In Capital, Marx ${ }^{14}$ said that the utility of a thing makes it a usevalue. The media industry would turn the contents that it manufactures and distributes, into the commodity which they were selling in the market. Economic of production and the distribution of content were going to move the basic orientation to the exchange value of commodity. Exchange value of commodity, at first

10 Grant, R.M. (2010): Contemporary strategy analysis: text and cases, 7. th. ed., John Wiley \& Sons Ltd.

11 Albarran, A.B. (2010): The Media Economy, New York, Routlege, Taylor \& Francis.

12 Doyle, G. (2013): Understandig Media Economy, Second Edition, Sage Publications Ltd.

13 Kung, L. (2013): Strategic Management in the Media - theory to practice, Sage Publications Ltd.

14 Marx, K. (1973): Kapital, Beogradski izdavačko-grafički zavod, Izdavačko preduzeće Prosveta, Beograd. 
sight, presents itself as a quantitative relation, as the proportion in which values in use of one sort are exchanged for those of another sort, a relation constantly changing with time and place ${ }^{15}$.

Upon his return from America, Baudrillard warned about the cultural products which were being assessed as a part of the exchange value. Referring to Adorn and Horkheimer ${ }^{16}$, he said that the classical Marxist critique of cultural industries (such as the one from Adorno and Horkheimer's Dialectic of Enlightenment) insist on exposing the deception for which the cultural industries that caused standardization of the products of culture were responsible ${ }^{17}$. Kunczik emphasized that the American theory and modernization policy believed in the convergence, according to which the development always ultimately leads to the American capitalism. And he mentioned that even Karl Marx, in the Capital, wrote that the capitalist production would impose itself worldwide: The country that is more developed industrially only shows, to the less developed the image of its own future ${ }^{18}$.

The history of the development of the different geographical areas and cultural pattern associated with social values, had a major impact on the dynamics and direction of development of the media industry. How much these factors are dong to be important in the future would depend on a number of other factors, from the inside, as well as from the environment of the observed geographic area, remains for some other future studies. This paper focuses on the difference between the domination of broadcasting and publishing in certain geographical areas.

\section{Hypotheses}

In our research, we start with two hypotheses:

1) Within the national media industry, broadcasting is the dominant category in the American continent and in the counties of Eastern Europe.

2) Broadcasting is the main driver of the media industry today.

According to the data collected from the scientific database EBSCO - Business Source Complete, and by using other professional literature from the area of the media industry, as well as everything that refers to that, it is obvious that the broadcasting, according to the income it generates is a dominant category within

15 Ibid.

16 Peović-Vuković K. (2014): “Je li vladajuća moda moda vladajuće klase? Ili što je marksizam učinio od strukturalizma?” ed., Hošić, I., Pažnja, odjeća, umjetnost, identitet, Zbornik radova, Tehnički fakultet Univerziteta u Bihaću, 177-189.

17 Ibid.

18 Kunczik, M., (2014): “Masovni mediji i njihov utjecaj na društvo”, ed. Malović, S. Masovno komuniciranje, Golden marketing - Tehnička knjiga, Zagreb. 
the media industry, in most of the countries that were included in the analysis. In our research, we are going to try and prove this claim by referring to the second hypothesis, which connects the growth of the media industry directly with the growth of broadcasting.

\section{Publishing in the global market}

According to the share of publishing in the national media industry, in the global market the leading country is Sweden with $48.5 \%$. It is followed by China, Germany, Japan, Italy, South Korea and Denmark with more than $40 \%$ in total share. At the last place on the list is the USA, with only $17.9 \%$. Alongside the USA are connected by underdeveloped media industry, due to a number of factors associated with historical, cultural, political and other reason.

The USA is a country with the largest generated incomes in the media industry in the world. In 2012, 255.1 billion dollars of turnover was generated in the media industry. Out of that, 45.6 billion dollars was in publishing and 146.6 billion dollars in broadcasting.

Figure 1: The share of publishing in total media industry per countries in 2012 (\%)

The share of publishing in total media industry per countries in 2012. (\%)

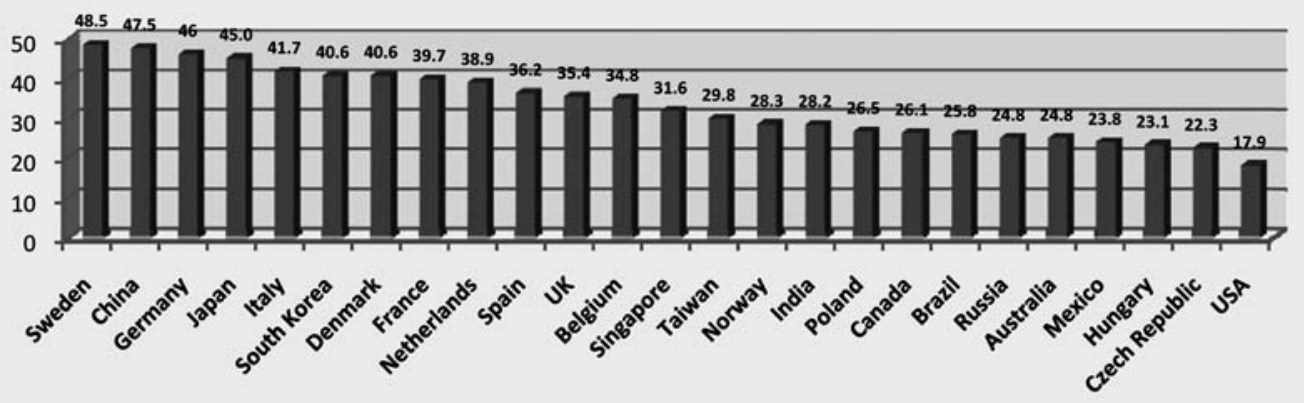

Source: EBSCO - own illustration

USA is also the leading country in dictating trends in the media industry, therefore, an open question remains for further scientific studies, about the fate of the publishing in the global market.

\section{Broadcasting in the global market}

In terms of share of broadcasting in the total media industry, Brazil is in the first place with almost $70 \%$ of broadcasting share in the total media industry. It is followed by Hungary, Mexico, USA, Taiwan, Czech Republic and Poland 
which have more than $50 \%$ of the share in the national media industry. Germany, Australia, Denmark, China, Norway and Sweden are at the bottom of the list. When compared with publishing we can notice Sweden as the country with the largest share of publishing and lowest share of broadcasting. The situation is similar with China, Germany and Denmark.

In contrast, Brazil, Hungary, Mexico and USA are the countries at the bottom of the publishing share, in the total media industry. The Czech Republic is at a high sixth place of the broadcasting share in the national media industry and at nest to last place in share in publishing one place ahead of the USA. The difference between the share of broadcasting and publishing is shown in Figure 3.

Brazil has the biggest difference between the share of broadcasting and publishing. The share of broadcasting is higher by 42.1 percentage points then the share of publishing. Hungary, USA, Mexico, Czech Republic, Taiwan and Poland are next, where the share of broadcasting is already higher by a quarter than the share of publishing. Canada, India, Russia and Spain have more than ten percentage pints of supremacy. These are all counties of the American continent and the Eastern Europe, except for Span and Asia. Spain is a country that geographically belong to the Western Europe, but along with Portugal, it is the poorest country in West Europe, and the roots for that can be traced back to the Middle Ages and the end of the mercantilism.

Figure 2: The share of bradcasting in total media industriy per countries in 2012. (\%)

\section{The share of broadcasting in media industry per countries in 2012. (\%)}

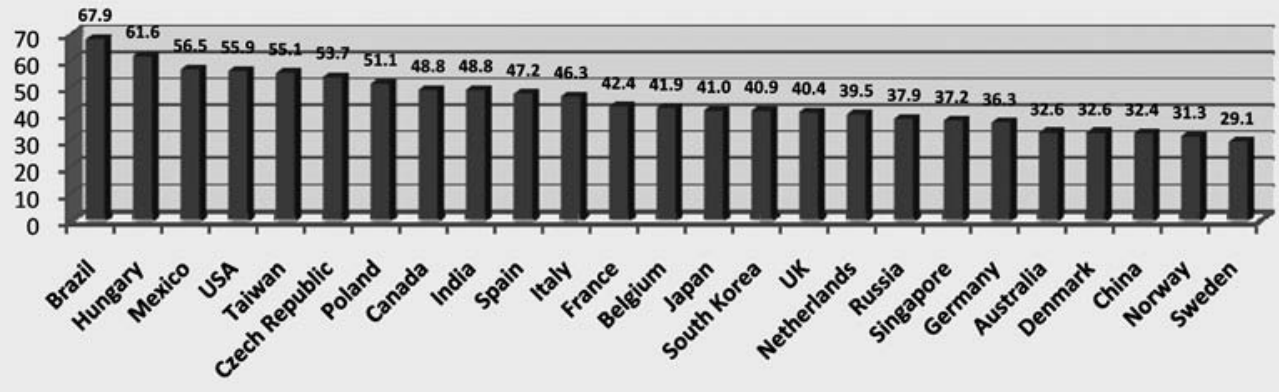

Source: EBSCO - own illustration

At the bottom of the list, with a negative margin of $19.4 \%$ of share is Sweden. A long tradition of publishing and education has remained until today. China, Germany, Denmark and Japan are also the ones that have negative differences. In this group of countries the Netherlands and South Korea are included with nearly identical relation between broadcasting and publishing. United Kingdom, Italy, Norway and France have positive differences which is less than 5 percentage points and which is within the borders on the global media industry level. 


\section{Growth rate}

According to the growth rates of the media industry, India with $12.3 \%$ and China with $11.8 \%$ are firmly in the lead. These are also the two countries with highest population number and that are rapidly developing some form of capitalism and with it their own media industry. They are followed by Brazil, Russia, Hungary, Poland, Singapore, Taiwan, South Korea and Mexico. There is no doubt that the growth rates are highest in the countries that had not developed any form of media industry and which are now rapidly making up for it. At the bottom of the list with negative growth rates are the countries of Western Europe, Japan and USA, where the media industry has already entered its mature phase and which are no longer achieving high growth rates.

Figure 3:Differences between share of broadcasting and publishing

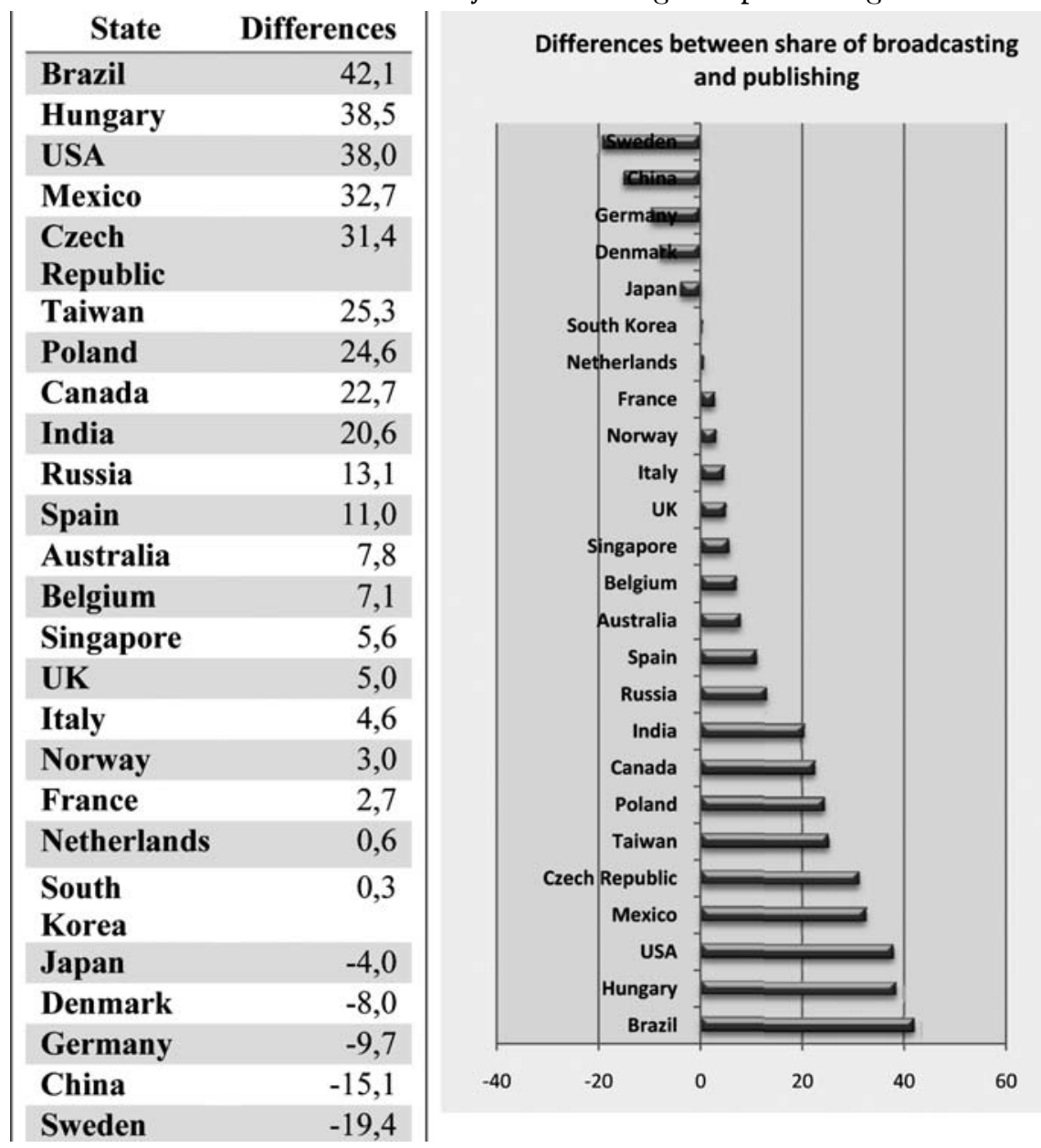

Source: EBSCO - own illustration 


\section{Questions for the discussion}

By analyzing and comparing the distribution of publishing and broadcasting within the national media industries, we can without any doubt claim that there are differences which depended on the factors that are not directly related to the media industry. In Figure 5, an overall presentation is made of the above demonstrated calculations and presentations of states of media industry according to various parameters of sorting.

Figure 4: Growth rate of global media industry in 2012. (\%)

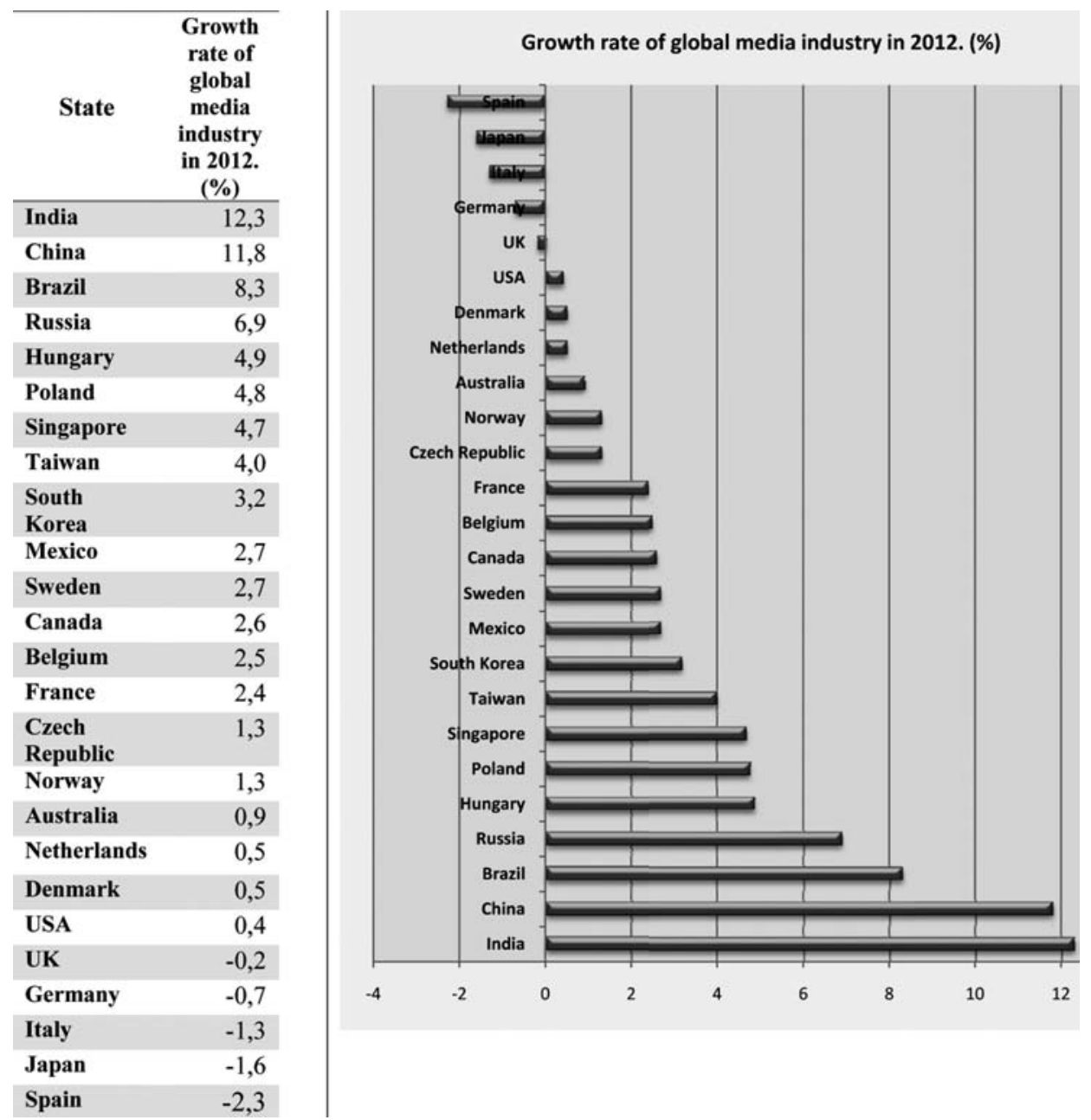

Source: EBSCO - own illustration 
The share of broadcasting is the larger in the countries of the American continent, Eastern Europe and Asia. This confirms our first hypothesis about the geographical distribution of the dominance of broadcasting (Figure 6). USA is homeland of broadcasting and most modern media corporation. At the end of modernism, it had begun to globalize its business and expand to other geographic areas. The domination of broadcasting is already considerable in Brazil, Mexico and Canada. Vertically integrated media corporations have delegated their models of development to neighboring countries by taking over local media organizations.

A similar model of development was repeated in Eastern Europe. Hungary, Czech Republic, Poland and partly Russia took over the similar patterns of development of the media industry. The expansion of the American media corporations is already getting its outlines on the Asian continent. Taiwan, India, Singapore and Australia already have a distinct dominance of broadcasting within the media industry. Japan and China still have a bigger dominance of publishing with the notion that China has joined the construction of the modern media industry and it takes time for the infrastructure to be built.

Figure 5: Growth rate of global media industry in 2012

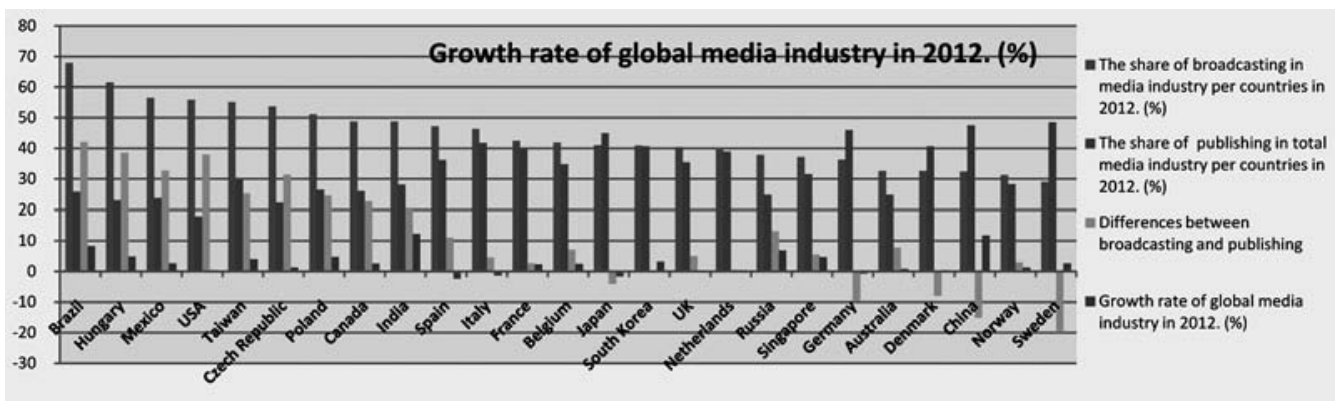

Source: EBSCO - own illustration

The second hypothesis cannot be full accepted. India and China are realizing the largest growth of the media industry. In India, broadcasting is the dominant category and along with China, it is a country with the largest population number. However, in China, publishing still has a dominant position and that does not confirm the hypothesis that the growth of the media industry is directly connected to the growth of broadcasting. States that follow on the list, according to the rates of growth of the media industry, Brazil, Russia, Hungary, Poland, Singapore and Taiwan, directly confirm the second hypothesis about the connection between broadcasting and growth of the media industry. 
Figure 6: The map of global media industry in 2012

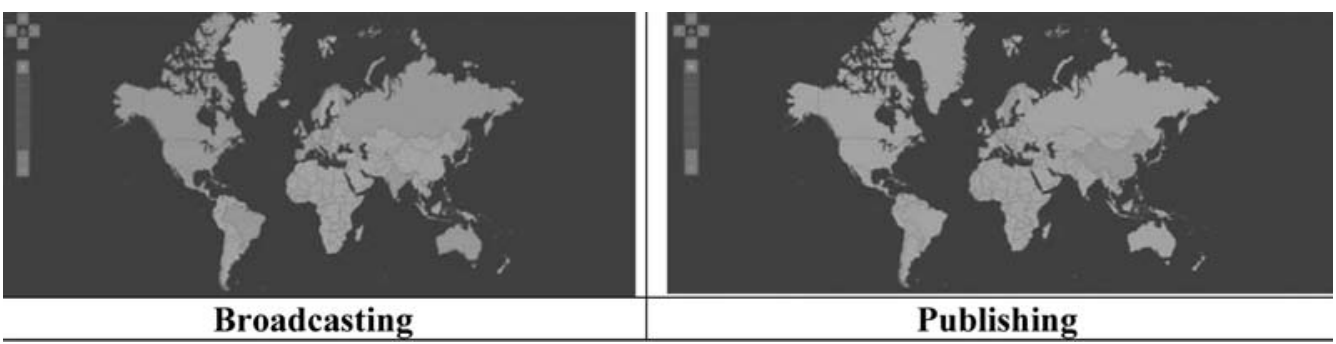

Source: Own Illustration

At the bottom of the list the countries are which have already developed the media industry and it has already reached a mature stage. Countries with rates of growth of the media industry less than one percent, Australia, the Netherlands, Denmark and USA have already developed the media industry, so it is difficult to expect higher growth rates. Along with them are Great Britain, Germany, Italy, Japan and Spain, with negative growth rates in the media industry. Distribution of countries from the bottom of the list confirms that the rate of growth of the media industry can not be gradually associated with growth and the incomes from broadcasting. In the same group are countries which have the dominance of broadcasting, such as USA and Great Britain, but also countries which have the dominance of publishing, like Japan and Germany.

Issues that arise after these data for some other studies refer to the determination of factors that affect the character of the development of certain categories of media industry. By analyzing the map of the world the dominance of broadcasting and the American way of expansion of media corporations can be noted in the entire American continent, in parts of Asia and Eastern Europe. The dominance of publishing can be found in Western Europe as well as in Japan and China. In South Korea, as one of the country with the oldest tradition of publishing, broadcasting slowly takes over the leading position.

Publishing in Europe remained a dominant category in the counties which have a strong tradition of education and which have evolved from a strong influence of the Enlightenment. Along with that, the publishing industry has developed in the countries of the north, with Protestant tradition, more than in the countries of South Europe. In the countries of Eastern Europe which had a weak connection to Protestantism, it had been easier to develop broadcasting as a model for the development of the media industry.

Broadcasting is a child of American media corporations, under domination of marshallian economic of production. Products and activities of media corporations enter into the exchange processes as the merchandise which has its exchange value. Kunczik referred to the commercial production of the content of the media industry from the position of communication sciences. Commercial 
production is usually thought to be, on one hand, culturally inferior and manipulated, or that it has manipulative contents and on the other hand, it claims that the features are selected in accordance with the wallet content and according to the wishes of the audience which would make them essentially democratic ${ }^{19}$. As Peovic Vukovic emphasized, the deception is in the fact that the industrial production of culture, which is in no way different from the industrial production of consumer goods, gives the impression of freedom of choice, while the truth is that is that all of these choices are reduced to the same selection ${ }^{20}$. How are the counties of north-western Europe going to develop the media industry will remain for some further research. Are they going to keep the tradition and historical legacies or will they support the development of broadcasting depends on a number of factors.

\section{Literature}

- $\quad$ Albarran, A.B. (2010): The Media Economy, New York, Routlege, Taylor \& Francis

- $\quad$ Best, S. and Kellner, D., (1991): Postmodern Theory - Critical Interrogations, The Guilford Press, New York

- Doyle, G. (2013): Understandig Media Economy, Second Edition, Sage Publications Ltd.

- Editorial Collective (2014): "Welcome to Media Industries", Media Industries Journal 1, 1-4

- Grant, R. M. (2010): Contemporary strategy analysis: text and cases, 7. th. ed., John Wiley \& Sons Ltd.

- Hicks, R.C.S. (2004): Expaining Postmodernism - Scepticism and Socialism from Rousseau to Foucault, Scholargy Publishing, Tempe, Arizona and New Berlin/Milwaukee, Wisconsin

- Kunczik, M. (2014): "Masovni mediji i njihov utjecaj na društvo", ed. Malović, S., Masovno komuniciranje, Golden marketing - Tehnička knjiga, Zagreb

- Kung, L. (2013): Strategic Management in the Media - theory to practice, Sage Publications Ltd.

- Kunzmann, P., Burkard, F. P., Wiedmann, F. (2001): Atlas filozofije, Golden Marketing Zagreb

19 Kunczik, M. (2014): “Masovni mediji i njihov utjecaj na društvo”, ed. Malović, S., Masovno komuniciranje, Golden marketing - Tehnička knjiga, Zagreb.

$20 \quad$ Peović Vuković K. (2014): “Je li vladajuća moda moda vladajuće klase? Ili što je marksizam učinio od strukturalizma?” ed., Hošić, I., Pažnja, Odjeća, Umjetnost, Identitet, Zbornik radova, Tehnički fakultet, Univerzitet u Bihaću, 177 -189. 
- Lunaček, V. (2004): Povijest ekonomskih doktrina, Dom i svijet, Ekonomski fakultet, Zagreb

- Malović, S., ed. (2014): Masovno komuniciranje, Golden marketing Tehnička knjiga, Zagreb

- Marx, K. (1973): Kapital, Beogradski izdavačko-grafički zavod, Izdavačko preduzeće Prosveta, Beograd

- Milardović, A. (1996): Uvod u politologiju, Pan - liber, Osijek

- Peović Vuković K. (2014): "Je li vladajuća moda moda vladajuće klase? Ili što je marksizam učinio od strukturalizma?” ed., Hošić, I., Pažnja, odjeća, umjetnost, identitet, Zbornik radova, Tehnički fakultet, Univerzitet u Bihaću, 177-189

- Piketty, T. (2014): Kapital u 21. stoljeću, Profil knjiga, Profil International, Zagreb

- Vercellone, C., ed. (2007): Kognitivni kapitalizam, Politička kultura nakladno-istraživački zavod, Zagreb 
Mr Joško Lozić

Sveučilište u Splitu

Odjel za stručne studije u Zagrebu

Dr Ante Rončević

Svučilište „Sjever“, Varaždin

Prof. dr Marin Milković

Svučilište „Sjever“, Varaždin

\section{GLOBALNA MEDIJSKA INDUSTRIJA U POSTMODERNI: DOMINACIJA RADIO-DIFUZIJE I TRADICIJA IZDAVAŠTVA}

\section{S a ž e t a k}

Cilj ovog rada je da ukaže na promene koje je donela postmoderna u globalnoj medijskoj industriji. Moderna je stvorena uporedo sa razvojem izdavaštva i trajala je nekoliko stotina godina. Postmoderna je nastala u krilu radio-difuzije i za samo par godina preuzela globalno tržište koje je bilo pod kontrolom izdavačkih kuća nekoliko stotina godina. Dve privredne krize s početka 21. veka, označile su ulazak globalne medijske industrije u zrelu fazu. Ulaskom u zrelu fazu, stabilizovala su se medijska tržišta privredno najrazvijenijih država. Prihodi više nisu beležili velike stope rasta, a pojedine države su počele da beleže i negativne stope rasta $\mathrm{u}$ poslednjih pet godina. Na globalnom tržištu se pozicioniralo nekoliko globalnih vertikalno integrisanih korporacija koje su strategijama preuzimanja izgurale manje konkurente sa tržišta.

Razdoblje zrelosti razotkrilo je specifičnosti medijske industrije i potrebu interdisciplinarnošću u naučnom pristupu. Analizirajući razvoj pojedinih kategorija medijske industrije na različitim geografskim područjima, očito je da postoje značajne razlike u stupnju njihovog razvoja. Na to su uticali različiti činioci od kojih se najznačajniji prepoznaju u istorijskom razvoju i kulturološkim različitostima pojedinih geografskih područja. Ekonomija kao naučna disciplina je relativno kasno, tek krajem dvadesetog veka, dala svoj značajniji doprinos proučavanju medijske industrije, pa je postala ravnopravan partner drugim naukama koje su već bile zastupljene u analizama. Medijska industrija, kao tipičan predstavnik postmoderne, zahteva holistički pristup kako bi se pronašli odgovori na postavljena pitanja.

Ključne reči: radio-difuzija, medijska industrija, postmoderna, izdavaštvo, menadžment 